\title{
Low-frequency sea level variability and impact of recent sea ice decline on the sea level trend in the Arctic Ocean from a high-resolution simulation
}

\author{
Kai Xiao ${ }^{1} \cdot$ Meixiang Chen $^{1} \cdot$ Qiang Wang ${ }^{2} \cdot$ Xuezhu Wang $^{1,2} \cdot$ Wenhao Zhang $^{1,2}$ \\ Received: 14 November 2019 / Accepted: 8 April 2020 \\ (C) Springer-Verlag GmbH Germany, part of Springer Nature 2020
}

\begin{abstract}
The Arctic Ocean is undergoing significant changes, with rapid sea ice decline, unprecedented freshwater accumulation, and pronounced regional sea level rise. In this paper, we analyzed the sea level variation in the Arctic Ocean based on a global simulation with 4.5-km resolution in the Arctic Ocean using the multi-resolution Finite Element Sea Ice-Ocean Model (FESOM). The simulation reasonably reproduces both the main spatial features of the sea surface height (SSH) and its temporal evolution in the Arctic Ocean in comparison with tide gauge and satellite data. Using the model results, we investigated the low-frequency variability of the Arctic SSH. Both the first two dominant modes of the annual-mean SSH evolution in the Arctic Ocean present decadal variability and can be mainly attributed to the variability of the halosteric height, thus the freshwater content. The first mode can be explained by the Arctic Oscillation (AO). The AO-related atmospheric circulation drives the accumulation and release of freshwater in the Arctic deep basin and the consequent ocean mass change over the continental shelf, leading to the antiphase changes in SSH between the shelf seas and the deep basin. The second mode shows an antiphase oscillation between the two Arctic deep basins, the Amerasian and Eurasian Basins, which is driven by the Arctic dipole anomaly (DA). The DArelated wind anomaly causes a spatial redistribution of freshwater between the two basins, leading to the antiphase SSH changes. By using a dedicated sensitivity simulation in which the recent sea ice decline is eliminated, we find that the sea ice decline contributed considerably to the observed sea level rise in the Amerasian Basin in the recent decades. Although the sea ice decline did not change the mean SSH averaged over the Arctic Ocean, it significantly changed the spatial pattern of the SSH trend. Our finding indicates that both the wind regime and ongoing sea ice decline should be considered to better understand and predict the changes in regional sea level in the Arctic Ocean.
\end{abstract}

Keywords Arctic Ocean $\cdot$ Sea level $\cdot$ FESOM $\cdot$ Decadal variability $\cdot$ Halosteric height $\cdot$ Sea ice decline $\cdot$ Freshwater content

\section{Introduction}

The Arctic is undergoing an unprecedented climate change, with air temperature increasing more than the global mean (a

This article is part of the Topical Collection on the 11th International Workshop on Modeling the Ocean (IWMO), Wuxi, China, 17-20 June 2019

Responsible Editor: Tal Ezer

Meixiang Chen

chenmeixiang@hhu.edu.cn

1 College of Oceanography, Hohai University, No. 1 Xikang Road, Nanjing 210098, China

2 Alfred-Wegener-Institut Helmholtz-Zentrum für Polar- und Meeresforschung, Bremerhaven, Germany phenomenon called Arctic amplification), significant sea ice extent and thickness reduction, Greenland ice sheet mass loss, and liquid freshwater accumulation (e.g., Proshutinsky et al. 2009; Serreze et al. 2009; Wang et al. 2005; Giles et al. 2012; Wang et al. 2018a). Sea surface height (SSH) is a natural integral indicator of global and regional ocean climate change (Church et al. 2013). Changes of regional sea level, which varies on a broad range of timescales, can deviate substantially from those of the global mean. Currently, there are still large uncertainties in the estimate of sea level changes in high latitudes, especially in the Arctic Ocean which has permanent and seasonal sea ice cover (Stammer et al. 2013).

In the Arctic Ocean, only along the Russian and Norwegian coastlines, there are some reliable continuous tide gauge records available starting from the 1950s, and a large proportion of the Russian sector tide gauge records was discontinued around 1990 (Proshutinsky et al. 2004; Henry et al. 2012; 
Svendsen et al. 2016). Since the early 1990s, altimetric satellite missions have provided observations of sea level in the Arctic Ocean south of $82^{\circ} \mathrm{N}$, allowing extraction of primary sea level variation patterns. Although conventional processing of satellite radar altimetry breaks down in the presence of sea ice, specialized satellite altimeter processing allows the extraction of SSH in ice-covered areas, making the study of sea level changes in the ice-covered Arctic Ocean possible (Laxon 1994; Peacock and Laxon 2004; Prandi et al. 2012a, 2012b; Giles et al. 2012; Cheng et al. 2015; Armitage et al. 2016; Svendsen et al. 2016; Rose et al. 2019).

Obvious sea level rise along the coast of Russian and Norwegian seas has been reported based on the tide gauge records (Proshutinsky et al. 2004; Henry et al. 2012). Rapid sea level rise in the Beaufort Gyre in the recent two decades was observed by satellite altimeter (Prandi et al. 2012b; Cheng et al. 2015; Carret et al. 2017; Rose et al. 2019). Using altimeter and Gravity Recovery and Climate Experiment (GRACE) space gravimetry data, Armitage et al. (2016) found a large seasonal cycle of Arctic SSH dominated by halosteric changes and a secular change of SSH determined by ocean mass contributions between 2003 and 2014. Carret et al. (2017) investigated the closure of the Arctic sea level budget since 2002 and found that the spatial pattern of sea level trends in the Arctic Ocean can be explained mainly by the halosteric component, but the trend of the Arctic mean SSH is dominated by mass contribution. These conclusions are consistent with the finding of Armitage et al. (2016) based on satellite data.

Despite great success with their applications, there are still several issues with the current observation datasets. First, as revealed by Carret et al. (2017), large uncertainties exist in the available Arctic sea level datasets, especially in the icecovered area and in different GRACE products. They also indicated that a large difference exists in the Arctic steric change between the results calculated directly from the temperature and salinity data and those obtained from the difference between altimetry and GRACE data. Second, the time series of sea level (since 1993) and ocean mass (since 2003) are not long enough to investigate the low-frequency Arctic sea level variability associated with the cyclonic and anticyclonic regimes of atmospheric circulation described by Proshutinsky and Johnson (1997), Proshutinsky et al. (2015) and the decadal sea level variability related to the Arctic Oscillation (AO) or North Atlantic Oscillation (NAO) observed by tide gauges along the coast (Proshutinsky et al. 2004; Henry et al. 2012; Calafat et al. 2013). Third, the satellite measurement does not cover the area north of $82^{\circ} \mathrm{N}$, making it difficult to understand the sea level variability for the whole Arctic Ocean.

Model simulations are often used to study regional and global sea level changes (e.g., Bindoff et al. 2007; Yin 2012; Church et al. 2013; Griffies et al. 2014; Slangen et al. 2017;
Meyssignac et al. 2017). Proshutinsky et al. (2007) revealed that ocean-sea ice models can well reproduce the variability of Arctic coastal SSH, although the spatial patterns and trends of the Arctic SSH differ significantly among models. Koldunov et al. (2014) investigated the interannual-to-decadal SSH variability in the Arctic Ocean using an Arctic regional model with an 8-km horizontal resolution. The SSH variability can be reasonably captured by their regional model, although it failed to reproduce the positive Arctic SSH trend observed over the last two decades, which might be due to open boundary conditions applied to the regional model. They also found that higher model resolution helps to improve the simulated spatial distribution of SSH. Using higher model resolution can better represent the changes in the spatial distribution of liquid freshwater in the Arctic Ocean (Wang et al. 2016a; Wang et al. 2018b). This implies that the variation of Arctic SSH could be better resolved with high resolution because the variation of SSH in the Arctic Ocean contains a significant halosteric component (Morison et al. 2012; Griffies et al. 2014; Armitage et al. 2016; Carret et al. 2017).

Global simulations with the Arctic Ocean resolved with 4.5-km-high resolution have become available recently (Wang et al. 2016b). Although these high-resolution simulations have been assessed with respect to their representation of sea ice, ocean salinity, and temperature (Wang et al. 2018a, 2018b, 2019), how well SSH in the Arctic Ocean is simulated is not evaluated yet. In this paper, we will first assess the Arctic SSH simulated in the high-resolution model setup described by Wang et al. (2018a, 2019). Then, the lowfrequency variability of Arctic SSH will be investigated using the model results. The impact of recent Arctic sea ice decline on the Arctic SSH will also be elucidated by using a dedicated sensitivity experiment.

The paper is organized as follows: in Section 2, we will briefly introduce the model used in our study, as well as the sea level observations using satellites and tide gauges. We will verify simulated mean SSH and sea level variability by comparing them with tide gauge and satellite-based SSH observations in Section 3. Investigation of low-frequency sea level variability and its mechanism is presented in Section 4 . Section 5 uses a climatology simulation to investigate the influence of recent rapid sea ice decline on Arctic Ocean sea level, and Section 6 finishes with concluding remarks.

\section{Model and observations}

\subsection{FESOM}

We use the results obtained from global simulations with the Finite Element Sea Ice-Ocean Model (FESOM v.1.4, Wang et al. 2014, Danilov et al. 2015). It is an ocean general circulation model with both the ocean and sea ice components 
working on unstructured triangular meshes, so it allows for multi-resolution simulations. This model has been applied and evaluated in various Arctic Ocean studies (e.g., Wang et al. 2016a, 2016b, 2016c, 2018a, 2018b; Wekerle et al. 2013, 2017a, 2017b; Müller et al. 2019). The model configuration used in this study is briefly described below.

The employed global mesh has $1^{\circ}$ nominal horizontal resolution in most parts of the world's ocean. The resolution is set to about $24 \mathrm{~km}$ north of $45^{\circ} \mathrm{N}$ and further increased to $4.5 \mathrm{~km}$ in the Arctic Ocean (defined by the Arctic gateways of the Bering Strait, Canadian Arctic Archipelago (CAA), Fram Strait, and Barents Sea Opening, see Fig. 1a). In the equatorial band and along the coast the resolution is also slightly increased. Forty-seven $\mathrm{z}$ levels are used with $10-\mathrm{m}$ resolution in the top $100 \mathrm{~m}$ and gradually coarsened downwards. For bottom topography, we use the $2-\mathrm{km}$ resolution version of the International Bathymetric Chart of the Arctic Ocean (IBCAO; Jakobsson et al. 2008) north of $69^{\circ} \mathrm{N}$ and the 1min resolution version of the General Bathymetric Chart of the Oceans (GEBCO) south of $64^{\circ} \mathrm{N}$. The topography is linearly interpolated between these two data sets for the range between $64^{\circ} \mathrm{N}$ and $69^{\circ} \mathrm{N}$.

The model is driven by the 3-hourly JRA-55 atmospheric forcing (Kobayashi et al. 2015) from 1958 to 2015 (the "control" run). The ocean starts from the PHC3 climatology temperature and salinity, and sea ice starts from the climatological state obtained in a previous simulation. To understand the impact of Arctic sea ice decline on the Arctic SSH, a sensitivity experiment is carried out using climatological atmospheric thermal forcing over the Arctic Ocean (the "climatology" run). The model configuration and forcing fields are the same as in the control run, except that the climatology of air temperature and downward longwave and shortwave radiation is used over the Arctic Ocean. The climatology is obtained by averaging the JRA-55 data from 1970 to 1999 for each 3-h segment. This sensitivity experiment branches from the control run in 2001 and is run using climatological atmospheric thermal forcing until 2015, covering the period when the SSH in the Beaufort Gyre (BG) region increased to an unprecedented level. It is shown in Wang et al. (2019) that the recent Arctic sea ice decline is well simulated by the control run and the decline is eliminated in the climatology run. Comparing the two simulations will help to reveal the impacts of the sea ice decline on the Arctic SSH.

\subsection{Observation data}

\subsubsection{Satellite altimetry}

We will use the mean dynamic topography (MDT) provided by the DTU13MDT (DTU hereafter) model, which has global coverage with a spatial resolution of 1 min based on 20 years (1993-2012) of both altimetry and Gravity Field and SteadyState Ocean Circulation Explorer (GOCE) satellite data (Andersen et al. 2015). It is the mean sea surface referenced to the geoid, so it can be used to assess the mean SSH obtained from our ocean model. Specialized satellite altimeter processing makes the retrieval of SSH from leads and polynyas in the ice-covered area possible, and now there are monthly $\mathrm{SSH}$ data from Envisat and CryoSat-2 satellites for both icecovered and ice-free areas up to $81.5^{\circ} \mathrm{N}$, as analyzed by Armitage et al. (2016). We will employ their SSH data in this paper. This data set has a spatial coverage up to $81.5^{\circ} \mathrm{N}$ on a $0.75^{\circ} \times 0.25^{\circ}$ longitude-latitude grid for the period 2003 2014. This satellite-derived monthly SSH product has been used for various Arctic Ocean studies (Armitage et al. 2016, 2017, 2018; Regan et al. 2019).
Fig. 1 a Model horizontal resolution and $\mathbf{b}$ ocean bathymetry. The Arctic Ocean is enclosed by the Canadian Arctic Archipelago, Fram Strait, Barents Sea Opening, and Bering Strait (black lines). Blue lines on land refer to the rivers flowing into the Arctic Ocean. Tide gauge locations are shown by circles, and circle colors indicate the correlation of the annual-mean SSH between the tide gauge and the control simulation (see also Table 1)

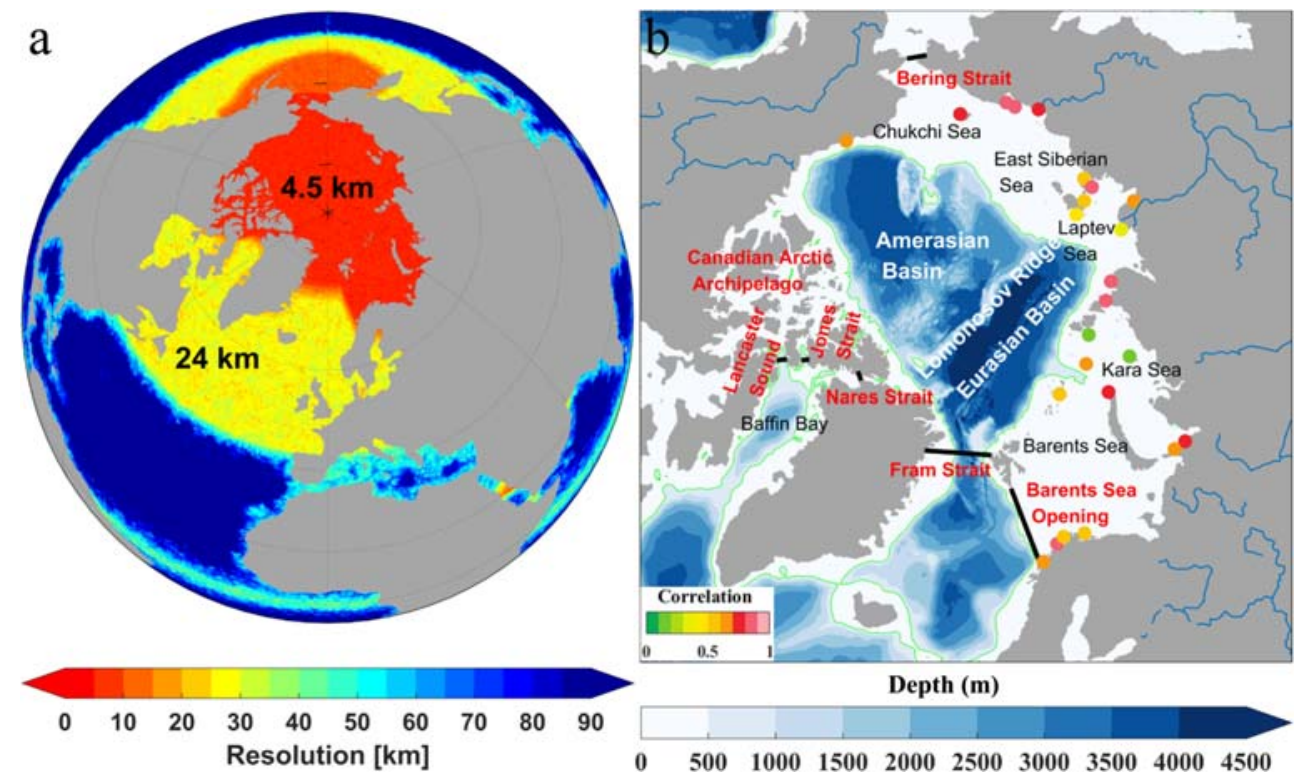




\subsubsection{Tide gauges}

The revised local reference (RLR) tide gauge records from the Permanent Service for Mean Sea Level (PSMSL) (Holgate et al. 2013) are used for the comparisons of coastal sea level with our model results. Monthly data from 24 stations within our research area are taken (Fig. 1b) and they cover most of the 1979-2015 period. Missing data are linearly interpolated for gaps that do not exceed 3 years, and stations with larger gaps are not included in our study. The tide gauge data are adjusted for the influence of the glacial isostatic adjustment (GIA) using the ICE-6G/VM5a model (Peltier et al. 2015).

\subsubsection{Reanalysis T-S data}

The simulated steric height is compared with the values calculated using the objectively analyzed ocean temperature and salinity of the EN4 data (Good et al. 2013). This data set is based on quality-controlled ocean temperature and salinity profiles, which consists of observational data from different projects to improve the Arctic data coverage.

\section{Evaluation of simulated SSH}

\subsection{Time-mean SSH}

We first compare the simulated spatial pattern of time-mean SSH with the DTU MDT for the period 1993-2012 (Fig. 2a, b, c) and with the SSH data of Armitage et al. (2016) for the period 2003-2014 (Fig. 2d, e, f). FESOM well reproduces the observed main characteristics of the SSH spatial pattern: high $\mathrm{SSH}$ in the Amerasian Basin with the maximum centered in the Beaufort Sea associated with the anticyclonic Beaufort Gyre and significant SSH gradients between the Amerasian Basin and Eurasian Basin associated with the Transpolar Drift Stream. This implies that the model reliably reproduces the main ocean circulation pattern in the Arctic region.

There are, however, certain model biases. Compared with the DTU data, the model underestimates the SSH north of Greenland and in the CAA and overestimates it in the central Arctic basin (Fig. 2c). Note that large uncertainties may also exist in DTU MDT especially to the north of Greenland and in the CAA as these areas are covered by multi-year sea ice (Johannessen et al. 2014). Although the simulated mean
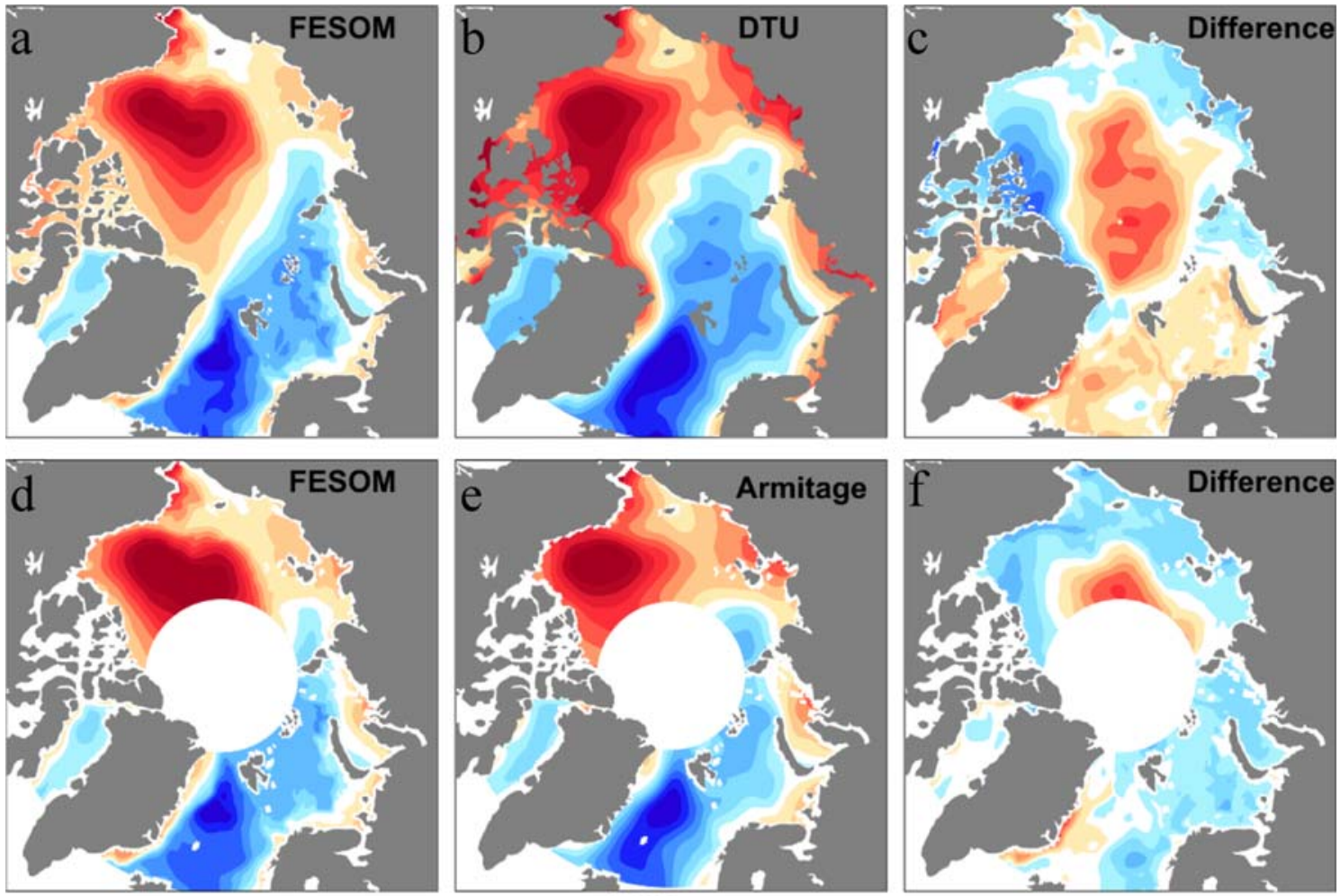

SSH , m

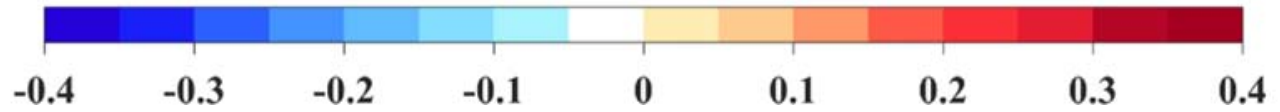

Fig. 2 Comparison of the mean SSH for the period 1993-2012 (a, b) and 2003-2014 (d, e). From left to right are a, d FESOM results, b DTU and e Armitage et al. (2016) observations, and $\mathbf{c}, \mathbf{f}$ the residual between FESOM and observations 
SSH for the period 2003-2014 is in better agreement with the result of Armitage et al. (2016), there is a moderate overestimation in the central Arctic Ocean and underestimation in other Arctic regions (Fig. 2f). The root-mean-square error (RMSE) of the simulated SSH referenced to the observational data of DTU and Armitage et al. (2016) is about $9 \mathrm{~cm}$. It is at the lower bound of the error range $(8-16 \mathrm{~cm})$ reported in previous studies on Arctic SSH with coarser models (Koldunov et al. 2014).

\subsection{Variability of SSH}

We use sea level data measured at 24 tide gauges within the Arctic Ocean (Fig. 1b) to evaluate the coastal SSH variation simulated by FESOM. The simulated SSH at the model grid points closest to tide gauge stations is taken, and correlations of both the monthly and annual-mean SSH between FESOM and tide gauges are calculated to assess the seasonal and interannual variability. The correlation between the monthly mean data is significant for all of the tide gauge stations, varying from the lowest value of 0.32 at the Ust Kara station located in the Kara Sea to the highest value of 0.92 at Honningsvag station located in the Barents Sea (Table 1). Averaged over different shelf seas, there is an excellent correlation in the Barents Sea $(R=0.86)$, Chukchi Sea $(R=0.86)$, and Beaufort Sea $(R=0.87)$. In the Kara, Laptev, and East Siberian Seas, where the influence of seasonal runoff is the greatest, the mean correlation is relatively smaller $(0.59,0.58$, and 0.70 , respectively). Our result is similar to the finding by Armitage et al. (2016), who found that monthly sea level anomalies derived from satellite altimeters have a better correlation with tide gauges in the Barents and Beaufort Seas and weaker correlation in the Kara, Laptev, and East Siberian Seas. The spatial distribution of the RMSE of altimeter SSH referenced to tide gauge data obtained in their analysis is also similar to that of our simulated SSH (not shown). The mean correlation coefficient averaged over all the stations is 0.69 , indicating that the model can reasonably represent the seasonal SSH variability along the Arctic coast.

The correlation of annual-mean SSH between the model and tide gauge data is lower than the correlation of monthly mean SSH at most of the stations (Table 1). However, the correlation of annual-mean SSH is still significant for most stations. Except at two stations in the Kara Sea, the correlation coefficients are in the range between 0.32 (at Nunai station located in the Laptev Sea) and 0.79 (at Andreia and Fedorova stations located in the Laptev Sea and Pevek station in the East Siberian Sea) (Fig. 1b and Table 1). The mean correlation coefficients averaged over different regions based on annualmean data are similar to those based on monthly data for most shelf seas, except the Beaufort and Barents Seas, where the correlation is much lower on the interannual timescale. The mean correlation coefficient of annual-mean SSH averaged over all the stations is 0.58 , suggesting that the interannual SSH variability along the Arctic coast is also reasonably well reproduced by FESOM, although slightly worse than the representation of seasonal variability.

Figure 3 a shows the anomaly of annual-mean SSH from the FESOM simulation and satellite observations (data from Armitage et al. 2016) averaged over the Arctic Ocean between $66^{\circ} \mathrm{N}$ and $81.5^{\circ} \mathrm{N}$. The satellite altimetry data contains the global mean sea level rise caused for example by land ice loss through Greenland and Antarctic ice sheet melting, which is not considered in the current simulation of FESOM. As our interest is in the regional dynamic sea level, the global mean sea level trend was removed before the comparison. The correlation of the simulated annual-mean SSH with the observation is 0.79 , revealing that FESOM well reproduced the observed interannual variability of Arctic mean SSH during the period 2003-2014. The model shows an SSH maximum in 2011, which was also reported by Armitage et al. (2016) and Volkov and Landerer (2013).

The Arctic Ocean is covered by sea ice during most time of the year, and sea ice coverage reaches minimum in September. In this month, the sea level observation based on satellite altimetry has the highest accuracy and thus, we further compare the spatial distribution of the changing rate of the September SSH from 2003 to 2014 between the model and altimetry data (Fig. 3b). For our purpose, we computed the linear trend to indicate the changing rate. Note that the word "trend" we used in the paper means the tendency during a certain period of analysis, which is not necessarily part of the long-term trend related to climate change.

The model well reproduces the spatial pattern of the SSH linear trend, with increasing SSH in the Amerasian Basin (centered at the Beaufort Gyre) and decreasing $\mathrm{SSH}$ in shelf seas. Both the model and observations consistently show that the most pronounced SSH trends are in the western Arctic Ocean, with opposite trends between the deep basin and the shelf region. The positive trends in the Amerasian Basin in the model are slightly weaker than the observed, and the simulated negative trends in the shelf seas are also weaker than the observed, especially in the Kara and Barents Seas. The rapid sea level rise in the Beaufort Gyre has been found in many studies (e.g., Prandi et al. 2012b, Morison et al. 2012; Cheng et al. 2015; Carret et al. 2017; Rose et al. 2019) and was often explained as a consequence of wind-driven freshwater accumulation (McPhee et al. 2009; Proshutinsky et al. 2009; Morison et al. 2012; Giles et al. 2012; Armitage et al. 2016). In Section 5, we will show that the recent sea ice decline actually contributed significantly to this sea level rise.

In conclusion, the model has a decent representation of the mean SSH and its variations in the Arctic region compared with the tide gauge and satellite data. In the following, we will investigate the low-frequency SSH variability in the Arctic Ocean using the model results. 
Table 1 Correlations of monthly and annual-mean FESOM and tide gauge $\mathrm{SSH}$

\begin{tabular}{|c|c|c|c|c|}
\hline Tide gauge & Location & Number (year) & $\begin{array}{l}\text { Correlation } 1 \\
\text { (monthly SSH) }\end{array}$ & $\begin{array}{l}\text { Correlation } 2 \\
\text { (annual SSH) }\end{array}$ \\
\hline Prudhoe Bay, Alaska & $\left(148.5^{\circ} \mathrm{W}, 70.4^{\circ} \mathrm{N}\right)$ & 20 & $0.87(0.01)$ & $0.56(0.01)$ \\
\hline Beaufort Sea & & 20 & 0.87 & 0.56 \\
\hline Vrangelia & $\left(178.5^{\circ} \mathrm{W}, 71.0^{\circ} \mathrm{N}\right)$ & 21 & $0.86(0.01)$ & $0.70(0.01)$ \\
\hline Chukchi Sea & & 21 & 0.86 & 0.70 \\
\hline Aion & $\left(168.0^{\circ} \mathrm{E}, 69.9^{\circ} \mathrm{N}\right)$ & 22 & $0.74(0.01)$ & $0.78(0.01)$ \\
\hline Pevek & $\left(170.3^{\circ} \mathrm{E}, 69.7^{\circ} \mathrm{N}\right)$ & 16 & $0.79(0.01)$ & $0.79(0.01)$ \\
\hline Ambarchik & $\left(162.3^{\circ} \mathrm{E}, 69.6^{\circ} \mathrm{N}\right)$ & 17 & $0.57(0.01)$ & $0.73(0.01)$ \\
\hline Shalaurova & $\left(143.2^{\circ} \mathrm{E}, 73.2^{\circ} \mathrm{N}\right)$ & 21 & $0.70(0.01)$ & $0.55(0.01)$ \\
\hline East Siberian Sea & & 19 & 0.70 & 0.71 \\
\hline Kigiliah & $\left(139.9^{\circ} \mathrm{E}, 73.3^{\circ} \mathrm{N}\right)$ & 34 & $0.80(0.01)$ & $0.78(0.01)$ \\
\hline Sannikova & $\left(138.9^{\circ} \mathrm{E}, 74.7^{\circ} \mathrm{N}\right)$ & 31 & $0.53(0.01)$ & $0.50(0.01)$ \\
\hline Kotelnyi & $\left(137.9^{\circ} \mathrm{E}, 76.0^{\circ} \mathrm{N}\right)$ & 32 & $0.50(0.01)$ & $0.45(0.01)$ \\
\hline Dunai & $\left(124.5^{\circ} \mathrm{E}, 73.9^{\circ} \mathrm{N}\right)$ & 30 & $0.50(0.01)$ & $0.32(0.07)$ \\
\hline Andreia & $\left(110.8^{\circ} \mathrm{E}, 76.8^{\circ} \mathrm{N}\right)$ & 15 & $0.77(0.01)$ & $0.79(0.01)$ \\
\hline Fedorova & $\left(104.3^{\circ} \mathrm{E}, 77.7^{\circ} \mathrm{N}\right)$ & 13 & $0.42(0.01)$ & $0.79(0.01)$ \\
\hline Tiksi & $\left(128.9^{\circ} \mathrm{E}, 71.6^{\circ} \mathrm{N}\right)$ & 31 & $0.55(0.01)$ & $0.58(0.01)$ \\
\hline Laptev Sea & & 27 & 0.58 & 0.60 \\
\hline Zhelania II & $\left(68.6^{\circ} \mathrm{E}, 77.0^{\circ} \mathrm{N}\right)$ & 14 & $0.53(0.01)$ & $0.67(0.01)$ \\
\hline Vise & $\left(77.0^{\circ} \mathrm{E}, 79.5^{\circ} \mathrm{N}\right)$ & 24 & $0.62(0.01)$ & $0.58(0.01)$ \\
\hline Ust Kara & $\left(64.5^{\circ} \mathrm{E}, 69.3^{\circ} \mathrm{N}\right)$ & 9 & $0.32(0.01)$ & $0.67(0.05)$ \\
\hline Izvestia Tsik & $\left(83.0^{\circ} \mathrm{E}, 76.0^{\circ} \mathrm{N}\right)$ & 34 & $0.76(0.01)$ & $0.06(0.72)$ \\
\hline Golomianyi & $\left(90.6^{\circ} \mathrm{E}, 79.6^{\circ} \mathrm{N}\right)$ & 27 & $0.52(0.01)$ & $0.15(0.44)$ \\
\hline Amderma & $\left(61.7^{\circ} \mathrm{E}, 69.8^{\circ} \mathrm{N}\right)$ & 31 & $0.77(0.01)$ & $0.61(0.01)$ \\
\hline Kara Sea & & 23 & 0.59 & 0.46 \\
\hline Hammerfest & $\left(23.7^{\circ} \mathrm{E}, 70.7^{\circ} \mathrm{N}\right)$ & 35 & $0.92(0.01)$ & $0.78(0.01)$ \\
\hline Honningsvag & $\left(26.0^{\circ} \mathrm{E}, 71.0^{\circ} \mathrm{N}\right)$ & 33 & $0.92(0.01)$ & $0.49(0.01)$ \\
\hline Vardo & $\left(31.1^{\circ} \mathrm{E}, 70.4^{\circ} \mathrm{N}\right)$ & 30 & $0.85(0.01)$ & $0.46(0.01)$ \\
\hline Krenkelia & $\left(58.1^{\circ} \mathrm{E}, 80.6^{\circ} \mathrm{N}\right)$ & 11 & $0.73(0.01)$ & $0.55(0.06)$ \\
\hline Tromso & $\left(19.0^{\circ} \mathrm{E}, 69.6^{\circ} \mathrm{N}\right)$ & 35 & $0.90(0.01)$ & $0.65(0.01)$ \\
\hline Barents Sea & & 29 & 0.86 & 0.59 \\
\hline Arctic Ocean & & 24 & 0.69 & 0.58 \\
\hline
\end{tabular}

For each station, we show the tide gauge location; number of years available; the correlation coefficients of monthly and annual SSH between simulated results and tide gauge data. The values in the round brackets indicate the significance level. The mean values for the Barents, Kara, Laptev, East Siberian, and Beaufort Seas, and the whole Arctic Ocean are in italics

\section{Interannual-to-decadal SSH variability}

Regional sea level often exhibits significant interannual-todecadal variability with considerably high amplitude that may even offset the long-term global trend in a relatively short period of time (e.g., Cazenave and Llovel, 2010; Stammer et al. 2013). Improved understanding of mechanisms driving the low-frequency sea level variability can help us to reduce uncertainties in regional sea level projections. Due to the shortness of satellite observations in the Arctic Ocean, research on interannual-to-decadal sea level variability in the Arctic Ocean was limited to coastal regions using tide gauge records (e.g., Proshutinsky et al. 2004; Henry et al. 2012; Calafat et al. 2013). In the following, we will use the SSH results of FESOM to investigate the interannual-to-decadal sea level variability over the whole Arctic Ocean for the period 1979-2015.

We performed an empirical orthogonal function (EOF) decomposition of the annual-mean SSH anomalies for the period 1979-2015. Before the EOF decomposition, the linear trend of SSH for this period (shown in Fig. 4e) was removed from the time series as our focus in this analysis is on the interannual and decadal variability. The trend is predominantly positive in the Arctic Ocean, and a small negative trend is found 


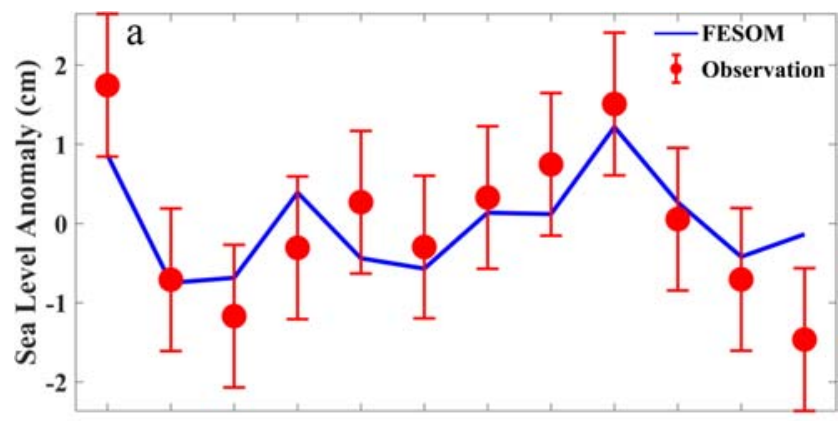

200320042005200620072008200920102011201220132014

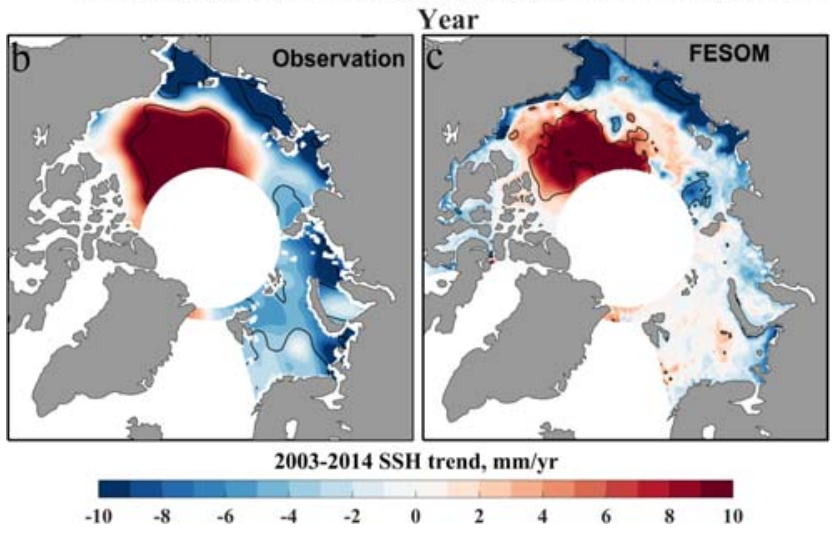

Fig. 3 a Anomaly of annual-mean SSH from observations and FESOM averaged over the Arctic Ocean between $66^{\circ} \mathrm{N}$ and $81.5^{\circ} \mathrm{N}$. b, c Spatial distribution of the rate of SSH change (linear trend) for September between 2003 and 2014. The satellite altimeter data is described in Armitage et al. (2016). Global mean sea level trend has been removed. The contour lines show the $95 \%$ confidence level

in the Eurasian Basin and along the coast of Alaska. The most significant SSH increase is centered in the Beaufort Gyre, with a rate of more than $5 \mathrm{~mm} /$ year.

The first three EOF modes of the annual-mean SSH anomaly and the corresponding principal component $(\mathrm{PC})$ time series are shown in Fig. 4 a, b, and c. The first EOF (EOF1) can explain $39.0 \%$ of the SSH variance, with obvious antiphase of $\mathrm{SSH}$ anomalies between deep basins (>500 m) and coastal seas $(<$ $500 \mathrm{~m}$ ) in the Arctic Ocean. The first PC (black curve in Fig. 4d) shows a decadal oscillation with the turning point at the early 1990s. This mode is consistent with the results of Koldunov et al. (2014) and Proshutinsky and Kowalik (2007), who got a similar EOF1 pattern using data from different models. This robust mode is also identified in the observed SSH based on recent satellite measurements by Armitage et al. (2018). They find that there are opposing responses of sea level between deep basins and coastal seas during positive and negative Arctic Oscillation (AO, Thompson and Wallace 1998) events. The AO is mainly in a positive phase before the 1990s and shifts to a negative phase since the mid-1990s. The variation in the $\mathrm{PC} 1$ coincides with this change, indicating that the relationship between this SSH mode and the AO state revealed for the short satellite period by Armitage et al. (2018) might be valid for much longer periods. The second
EOF explains about $14.6 \%$ of the SSH variance. It shows a decadal oscillation of SSH with antiphase between the Amerasian and Eurasian Basins. The spatial pattern of this mode suggests that the Arctic atmospheric dipole anomaly (DA) might be the driving mechanism. The DA is the second mode of the Arctic sea level pressure (SLP) first proposed by Wu et al. (2006) and further linked to the Arctic sea ice minima, sea ice export, and recent sea ice decline (Wang et al. 2009; Lei et al. 2015, 2016). The third mode explains $8.9 \%$ of the $\mathrm{SSH}$ variance and shows an oscillation between the Russian coast with part of the deep basin and the rest of the Arctic Ocean, which may be related to the Arctic basin-scale natural decadal oscillation in terms of first baroclinic Kelvin wave, as discussed in depth by Ikeda (1990) and Wang et al. (2005). As the first two EOF modes explain the majority of the SSH variability, in this study, we will focus on these two modes.

According to the evolution of the PC1 time series, we analyzed the changes of SSH and its components during the periods of 1979-1993 and 1994-2010 separately, as they are two successive periods with dramatic and inverse sea level changes. The period 1979-1993 shows a decrease of SSH in the central Arctic Ocean and an increase of SSH on the continent shelf (Fig. 5a). A similar pattern of SSH trends appears in 1994-2010 (Fig. 5e) but with signs opposite to the period of 1979-1993. In order to explore the cause of the SSH changes during the two periods, we further analyze the changes of steric height and ocean mass, which contribute to the total $\mathrm{SSH}$ changes together. The steric height is separated into the halosteric and thermosteric parts.

It is clear that the halosteric component (Fig. $5 \mathrm{~b}$ and f) explains most of the SSH changes, especially in the deep basin. This can be explained by the fact that changes in sea water density in the Arctic Ocean are mainly determined by salinity due to the low thermal expansion coefficient at low temperature and large haline contraction coefficient at relatively lower salinity (Griffies et al. 2014). The thermosteric component (Fig. $5 \mathrm{c}$ and g) contributes very little to the total SSH changes in the studied region. The trends of halosteric and thermosteric heights are opposite in the Eurasian Basin. The decadal variability of Atlantic Water inflow, which is warm and saline, could be responsible for this phenomenon (Dmitrenko et al. 2008). Ocean mass changes (Fig. $5 \mathrm{~d}$ and h) have a little contribution in the deep basin but are relatively important on the continental shelf. The ocean mass changes on the shelf in the two periods are opposite and they are linked to the SSH changes in the central Arctic. When SSH decreases in the central Arctic, the divergence of surface freshwater means piling of the water onto the shelf, thus increasing the ocean mass there (Fukumori et al. 2015; Armitage et al. 2018). The two periods are characterized by opposite changes in the SSH in the deep Arctic basin, so the changes in the ocean mass on the continental shelf are also opposite. Overall, for the longterm variability of SSH in the Arctic Ocean, the changes in the 

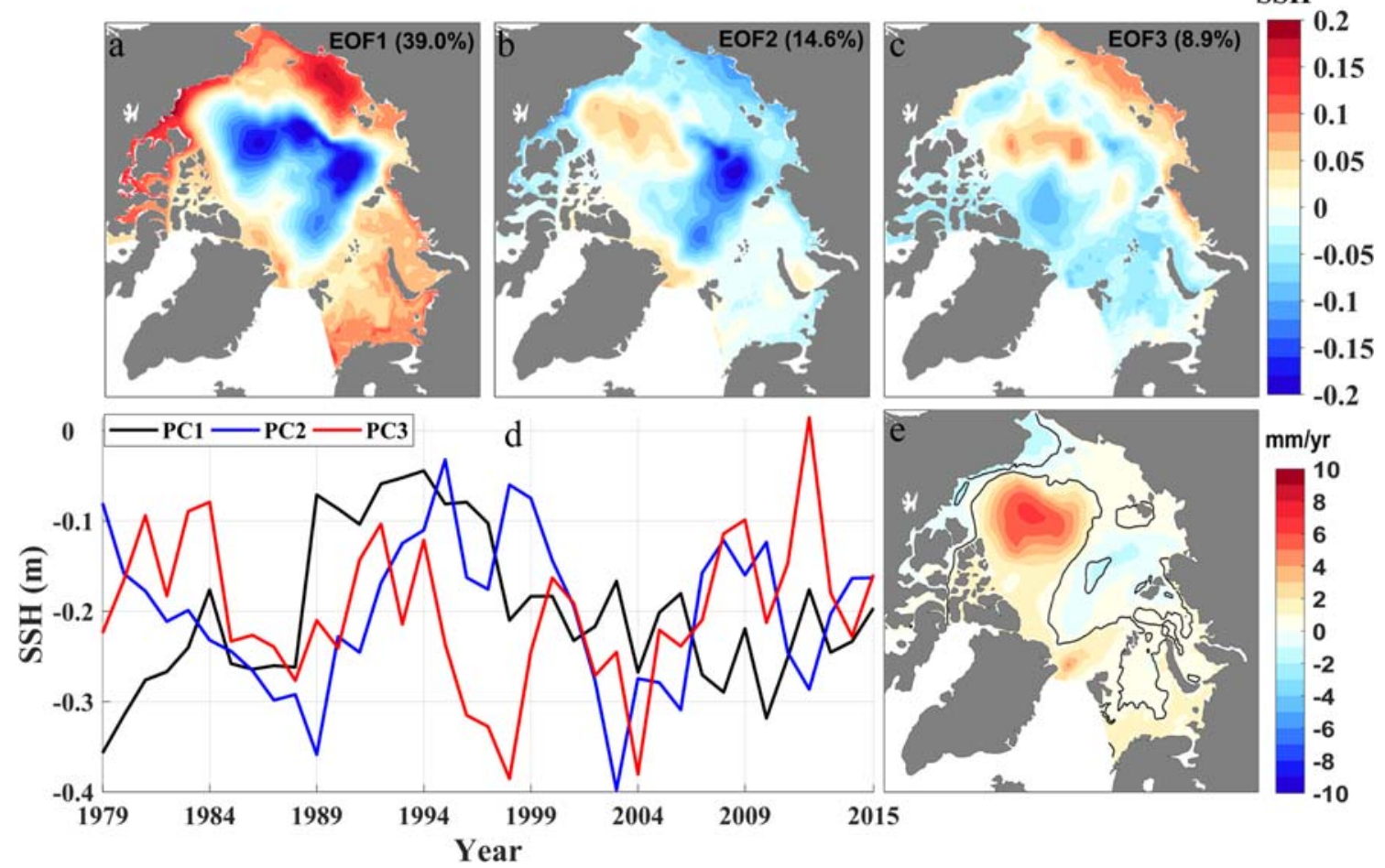

SSH

Fig. 4 a, b, $\mathbf{c}$ The first 3 EOF modes of the detrended annual-mean SSH and $\mathbf{d}$ the corresponding PC time series for the period 1979-2015. e The spatial distribution of the SSH linear trend for the same period. The black contour lines show the $95 \%$ confidence level

halosteric height play a dominant role, while the consequent mass changes are relatively important in the shelf seas. The halosteric changes in the deep basin and the opposite mass changes over the shelf together lead to the dominant mode revealed by the EOF1 (Fig. 4a).
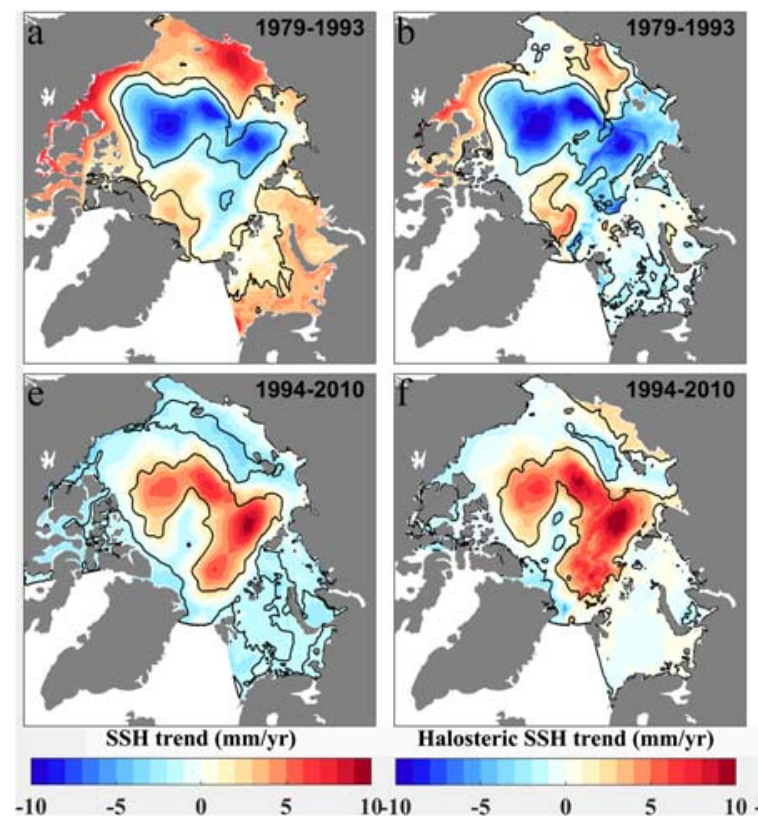

Fig. 5 Linear trends of the SSH and its different components for $\mathbf{a}, \mathbf{b}, \mathbf{c}, \mathbf{d}$ 1979-1993 and e, f, g, h 1994-2010 simulated by FESOM. From left to right: total SSH trend, trend of halosteric height, trend of thermosteric
Since there is no continuous three-dimensional temperature and salinity observation that covers the whole Arctic Ocean, we compute steric changes from the objectively analyzed EN4 dataset to assess the steric changes calculated based on the model output. Figure 6 shows the trends of steric height
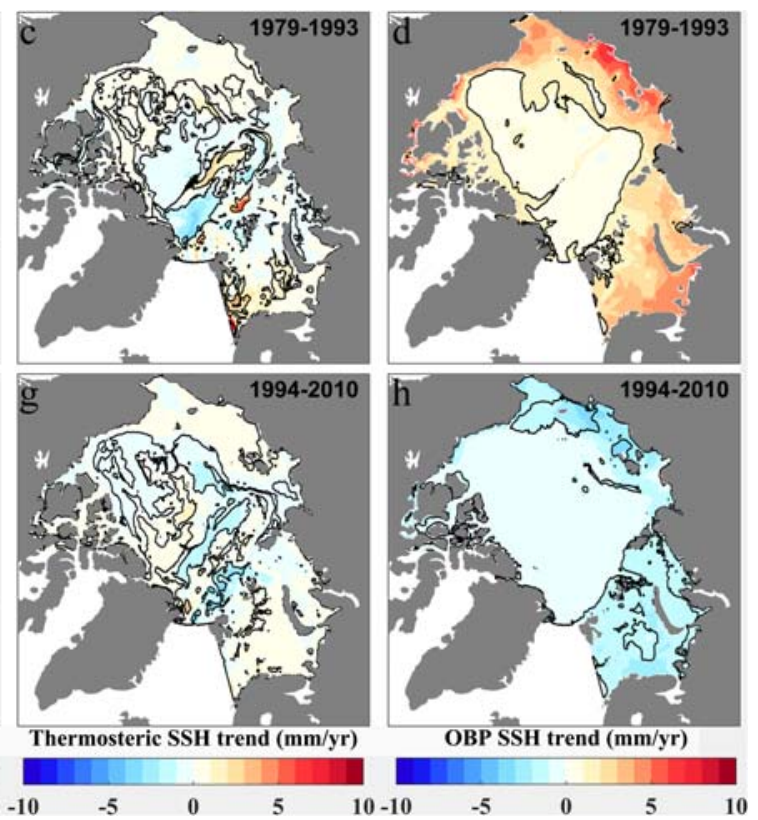

height, and trend of ocean bottom pressure. The black contour lines show the $95 \%$ confidence level 

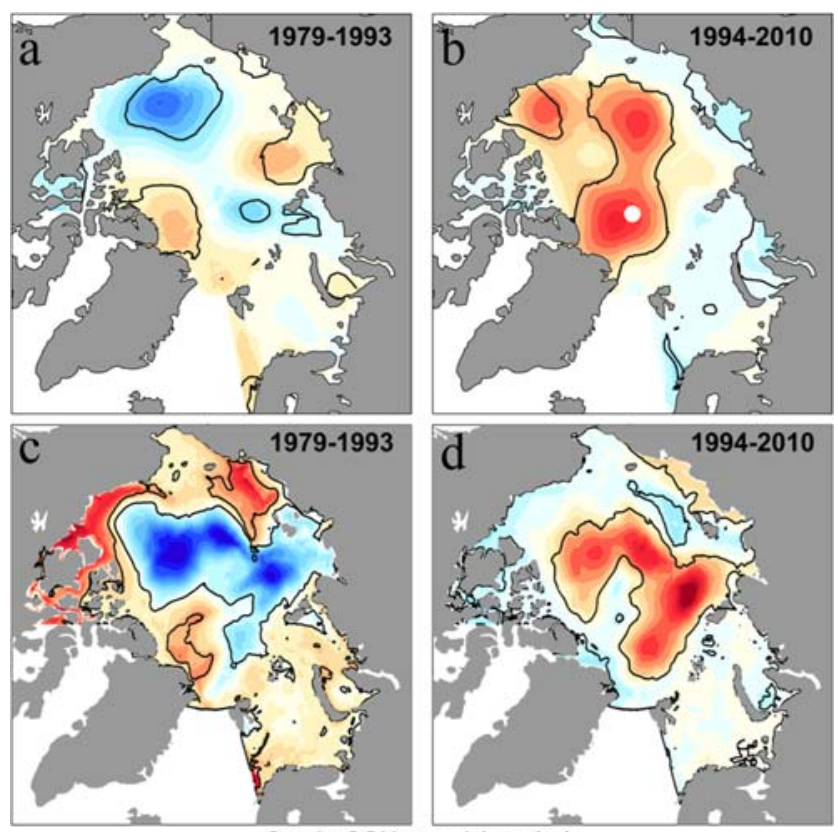

Steric SSH trend $(\mathrm{mm} / \mathrm{yr})$

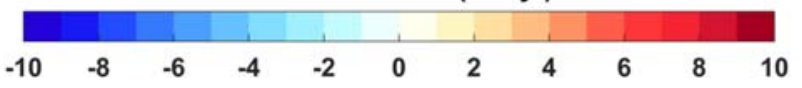

Fig. 6 Trend of total steric height for a, c 1979-1993 and b, d 1994 2010: a, b EN4 data and c, d FESOM simulation. The contour lines show the $95 \%$ confidence level

derived from EN4 and FESOM simulations for the same periods. Despite limited T-S profiles in the Arctic Ocean included in the EN4 dataset, the steric changes from the model output and EN4 data share some similarities. Both of them show negative trends in the Amerasian Basin in the early period and positive trends in the later period. However, there is a difference in the details of the spatial patterns. The main difference is in the eastern Eurasian Basin, where only the model has strong negative or positive trends. In the Amerasian Basin, the strong trends are located farther from the coast in the model. The difference between the model and the EN4 data could be due to biases in the spatial pattern of salinity in both datasets.

As the decadal variability of halosteric height dominates the low-frequency variability of the $\mathrm{SSH}$, changes in the Arctic liquid freshwater content (FWC) can serve as a key indicator for the SSH changes. Observations have shown that the Arctic liquid FWC has been increasing since the mid1990s (Proshutinsky et al. 2009; McPhee et al. 2009; Giles et al. 2012; Polyakov et al. 2013), which is mainly due to the freshwater accumulation in the Amerasian Basin (Rabe et al. 2014). The FWC variability in the Beaufort Gyre and Amerasian Basin was suggested to be forced by the winddriven convergence/divergence (Proshutinsky et al. 2002, 2015; Giles et al. 2012). Meanwhile, the FWC change of the Arctic Ocean is also connected with the freshwater exchange between the Arctic Ocean and the Atlantic and Pacific Oceans
(Woodgate et al. 2012; Armitage et al. 2018). To understand the decadal halosteric height variability in the Arctic Ocean, we calculate the total liquid FWC within the Arctic Ocean and the total liquid freshwater transport (FWT) (positive into the Arctic Ocean) across the gateway transects defined in Section 1. FWC and FWT are calculated according to Eqs. (1) and (2):

$$
\begin{aligned}
& \mathrm{FWC}=\iiint_{D} \frac{S_{\mathrm{ref}}-S}{S_{\mathrm{ref}}} \mathrm{dxdydz} \\
& \mathrm{FWT}=\iint_{A} \frac{\left(S_{\mathrm{ref}}-S\right)}{S_{\text {ref }}} V_{n} d A
\end{aligned}
$$

where $S_{\text {ref }}=34.8$ is the reference salinity, $\boldsymbol{S}$ is salinity, and $\boldsymbol{D}$ is the depth where salinity is equal to the reference salinity. $\boldsymbol{A}$ and $V_{n}$ in Eq. (2) denote the area of the transect and velocity normal to the transect. Wang et al. (2019) showed that the Arctic liquid FWC in the simulation used in this paper is in very good agreement with observations (Fig. 3 in their paper).

The AO is the leading mode of the SLP variability for the extratropical Northern Hemisphere (Thompson and Wallace 1998), which influences not only the sea ice but also the ocean state. It drives the decadal Arctic sea ice oscillation (e.g., Wang and Ikeda 2000, 2001; Ikeda et al. 2001; Wang et al. 2005) and the Arctic FWC changes as well (Proshutinsky et al. 2015; Armitage et al. 2018). The impact of the AO on the FWC can explain the dominant mode of the SSH variability shown in Fig. 4a. Here we hypothesize that the influence of the AO-related wind forcing on FWC will accumulate over time. Indeed, the cumulative sum of the AO index since 1979 is well correlated with the liquid FWC in the Arctic deep basin (the correlation coefficient is -0.77 at the 0.01 significance level, Fig. 7a). Both of them show decadal variability with a turning point at about 1994, suggesting that this variability explains the dominant mode of the SSH variability shown in Fig. 4a. Because of the long memory of the ocean to the wind forcing, the status of the FWC and SSH in a certain year is the consequence of not only the ongoing atmospheric forcing change but also the accumulative effect of the forcing in the past. We also found that the decadal change of the liquid FWC in the Arctic deep basin is well correlated with the total liquid freshwater transport through the Arctic gateways (the correlation coefficient is 0.92 at the 0.01 significance level, Fig. 7a). The correlation between the liquid freshwater transport and the SSH is opposite between the deep basin and the shelf region (Fig. 7b). When AO is in the negative phase, the anomalous anticyclonic atmospheric circulation accumulates freshwater towards the deep basin and increases the halosteric height and thus SSH in the deep basin. The associated release of freshwater from the continental shelf reduces the ocean mass and thus SSH in the Arctic marginal seas. The latter changes the SSH gradient with the sub-Arctic seas and further causes a positive anomaly in the freshwater transport to the 


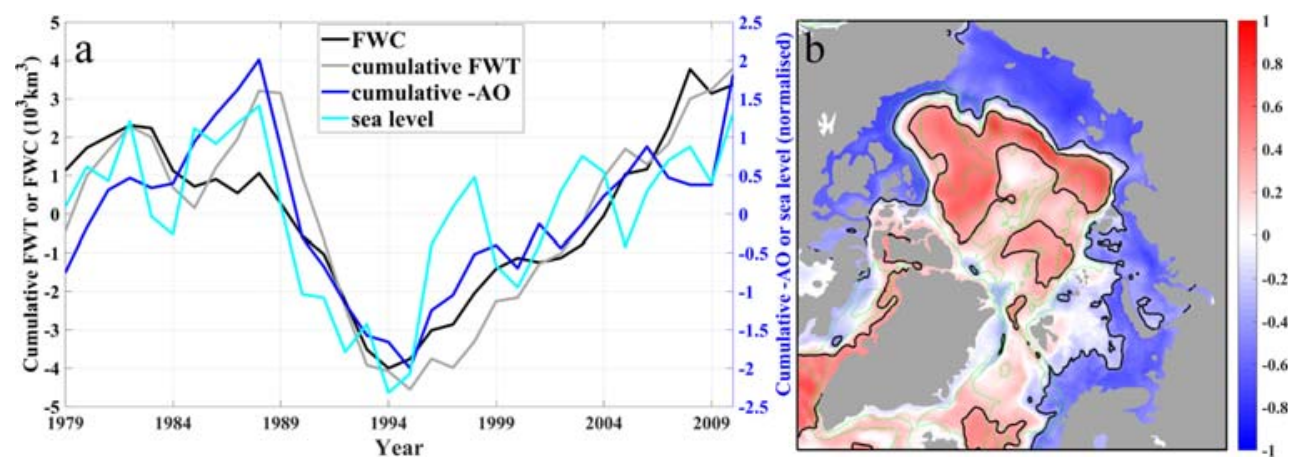

Fig.7 a The relationship between the cumulative sum of the Arctic Oscillation index (AO; blue line), the cumulative liquid freshwater transport into the Arctic Ocean (gray line), the liquid freshwater content (FWC; black line), and the average sea surface height (SSH; bright blue line) in the Arctic deep basins (>500 m). The AO index is reversed (multiplied by -1 ). The cumulative $\mathrm{AO}$ and the $\mathrm{SSH}$ are normalized by their respective standard deviations. b Correlation between liquid freshwater transport into the Arctic Ocean and the sea level for the period 1979-2015. The green contour lines indicate the 500-, 2000-, and $3500-\mathrm{m}$ isobaths. The black contour lines show the $95 \%$ confidence level
Arctic Ocean. The impact of SSH gradients on ocean transports through Arctic gateways is consistent with previous studies (e.g., Wekerle et al. 2013; Köhl and Serra 2014). When the AO is in a positive phase, the opposite processes occur. The spatial pattern of Fig. $7 \mathrm{~b}$ is similar to the pattern of EOF1 in Fig. 4a, which further confirms that the AO-related atmospheric forcing is responsible for the freshwater release/ accumulation and the dominant mode of low-frequency SSH variability in the Arctic Ocean.

The second mode (EOF2) of the low-frequency SSH variability shows an antiphase pattern between the two deep basins in the Arctic Ocean (Fig. 4b). To better reveal the antiphase relationship between the two deep basins, we carried out another EOF decomposition for the SSH only in the deep Arctic basin (Arctic area with topography deeper than $500 \mathrm{~m}$ ). The first mode shares the similarity to the first mode shown in Fig. 4a; for the second mode (shown in Fig. 8a), although the pattern is also similar to the second mode of the decomposition over the whole Arctic Ocean (Fig. 4b), it reveals a stronger antiphase relationship between the two deep basins as shown by their very similar magnitude of anomalies. The corresponding PC2 (red curve in Fig. 8c) is well correlated with the cumulative sum of the annual DA index (the PC2 of the monthly SLP north of $70^{\circ} \mathrm{N}$ ), suggesting that this SSH mode is driven by the atmospheric variability associated with the DA. After subtracting the first SSH mode, the remaining SSH signal has a strong correlation with the cumulative sum of the DA index: with positive values in the Amerasian Basin and negative values in the Eurasian Basin (Fig. 8b). This correlation pattern is very similar to the EOF2 of the SSH (cf. Fig. 8 a and b).

The SLP associated with the DA has two action centers in the Arctic and the corresponding wind anomaly is by large meridional, although the exact locations of the SLP action centers change with seasons (Wu et al. 2006; Wang et al. 2009). During a positive phase of the DA, the SLP has a positive anomaly on the side of the CAA and negative one on the Eurasian side. Previous studies on the DA have mainly focused on the impact of the associated wind anomaly on Arctic sea ice. For example, it was found that the Transpolar Drift Stream is strengthened during the positive DA phase and more sea ice is flushed out of the Arctic basin into the Barents and Greenland seas (Wu et al. 2006; Wang et al. 2005, 2009; Lei et al. 2015, 2016). In this study, we found that the DA also influences the SSH over the Arctic deep basin. During the positive DA, the wind anomaly not only strengthens the Transpolar Drift Stream but also induces an ocean surface Ekman transport anomaly directed from the Eurasian Basin towards the Amerasian Basin. The latter increases the FWC, thus the SSH, in the Amerasian Basin, and reduces the FWC, thus the SSH, in the Eurasian Basin. We note that the SSH variability in the Arctic deep basins is mainly determined by the halosteric height. During the negative phase of the DA, the opposite scenario occurs. Therefore, the DA-related atmospheric forcing is responsible for the antiphase of the $\mathrm{SSH}$ anomaly between the Amerasian and Eurasian Basins (Fig. 8). The SSH varies following the "cumulative effect" of the DA, as the spatial redistribution of freshwater does.

In conclusion, the dominant mode of the low-frequency Arctic SSH variability shows changes with antiphase between the deep basin and the continental shelf on the decadal timescale. The decadal variability of the Arctic SSH is mainly caused by halosteric variability, which is associated with the variability of Arctic Ocean liquid FWC driven by the AOrelated wind forcing. The second low-frequency mode with the antiphase of SSH anomalies between the Amerasian and Eurasian Basins on the decadal timescale can be explained by the DA-driven liquid FWC redistribution between the two deep basins. 
Fig. 8 a The second EOF mode of the detrended annual-mean $\mathrm{SSH}$ in the Arctic deep basin (area deeper than $500 \mathrm{~m}$ ) for the period 1979-2015. b The correlation between the cumulative sum of the dipole anomaly (DA) index and the sea level with its first mode of EOF subtracted for the period 1979-2015. The green contour lines indicate the 500-, 2000-, and 3500-m isobaths. The black contour lines show the $95 \%$ confidence level. c Time series of the cumulative sum of the DA index and the PC2 of the SSH in the Arctic deep basin. Both are normalized by their respective standard deviations. The correlation coefficient is 0.54 at the 0.01 significance level

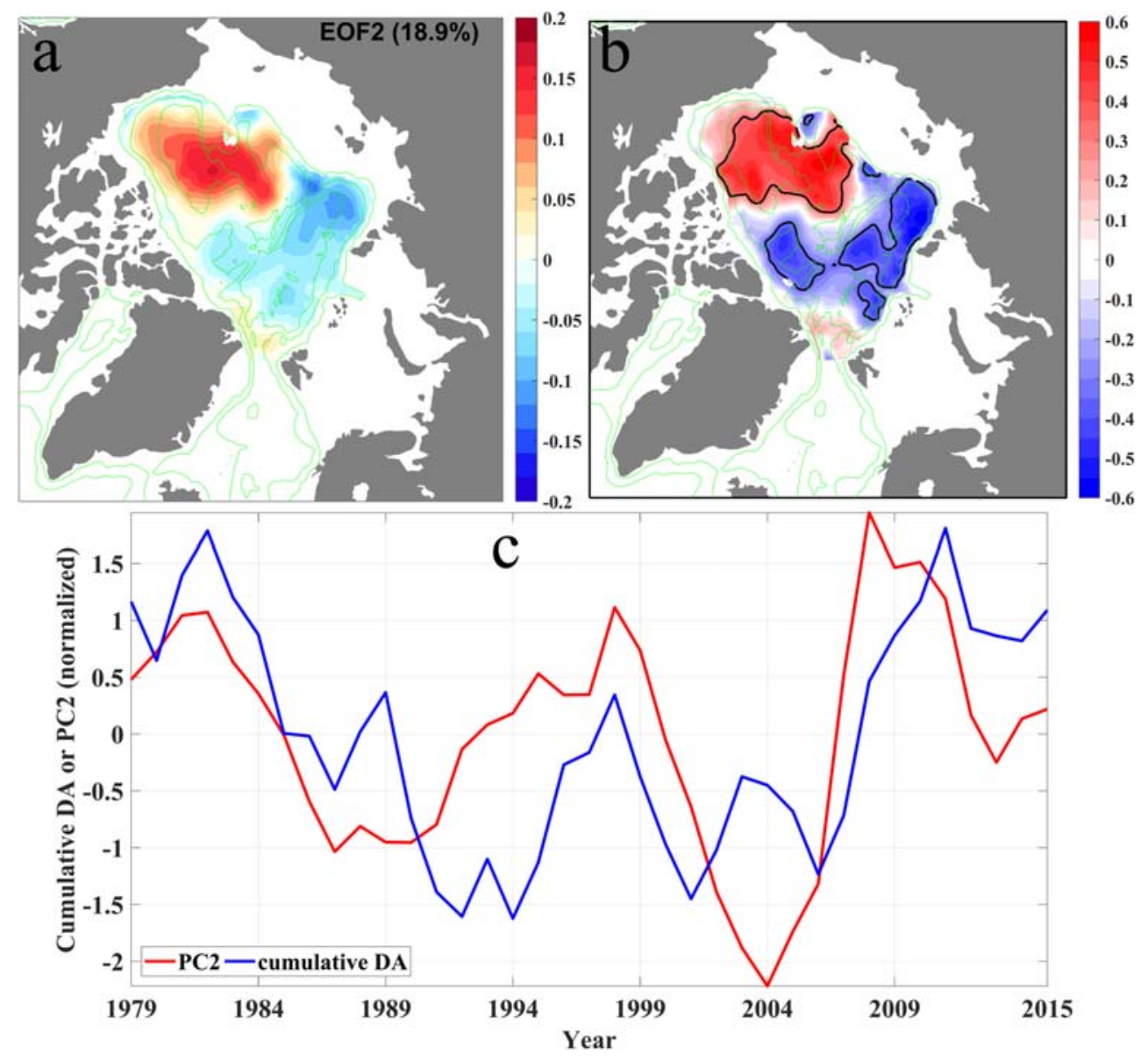

\section{Impacts of recent sea ice decline on the Arctic sea level change}

The Arctic SSH has strong low-frequency variability, as discussed in Section 4. However, since the 2000s, significant sea level rise has been observed in the Beaufort Gyre region, which is associated with freshwater accumulation (Giles et al. 2012; Morison et al. 2012; Long et al. 2012; Armitage et al. 2016). Meanwhile, significant sea ice decline has been observed in the last two decades (Kwok et al. 2009; Stroeve et al. 2012; Laxon et al. 2013). Sea ice decline can influence not only the freshwater budget through meltwater but also the ocean surface stress (Martin et al. 2014). Although the recent sea ice decline increases the FWC in the Beaufort Gyre significantly (Wang et al. 2018b), it reduces the FWC in the Eurasian Basin (Wang et al. 2019), which implies further impacts on the SSH. In this section, we will quantify the impacts of the recent sea ice decline on the SSH in the Arctic Ocean using model simulations. In the climatology run, the Arctic sea ice decline is eliminated. The variation of the SSH in this run is then mainly due to wind forcing, and the difference between the control run and the climatology run can reveal the impacts of sea ice decline on the SSH.
We found two completely different patterns of SSH trends in the Arctic Ocean over the studied period for the control run and climatology run (Fig. $9 \mathrm{a}$ and b). Although the control run shows significant positive trends in the Amerasian Basin, as expected from satellite observations (e.g., Prandi et al. 2012b; Cheng et al. 2015; Armitage et al. 2016; Carret et al. 2017; Rose et al. 2019) and ocean hydrography (Rabe et al. 2014), positive trends in the climatology run are rather located in the Eurasian Basin and the central Arctic over the period considered. The sea ice decline leads to an increase in the SSH in the Amerasian Basin and a decrease in the Eurasian Basin.

In the Amerasian Basin, the sea level has an increasing tendency until 2008 in both simulations. Afterwards, it continues to rise and retain at a high level in the control run but declines in the climatology run (Fig. 9d). In the Eurasian Basin, the sea level in the control run decreases after 2004 while in the climatology run it increases (Fig. 9e). However, the mean SSH averaged over the whole deep basin is similar between the control and climatology runs (Fig. 9f), and the mean SSH averaged over the entire Arctic Ocean including the coastal seas also has little difference between the runs (Fig. 9g). This means that the recent sea ice decline significantly changes the spatial pattern of SSH, although it does not change the mean SSH over the Arctic Ocean. 

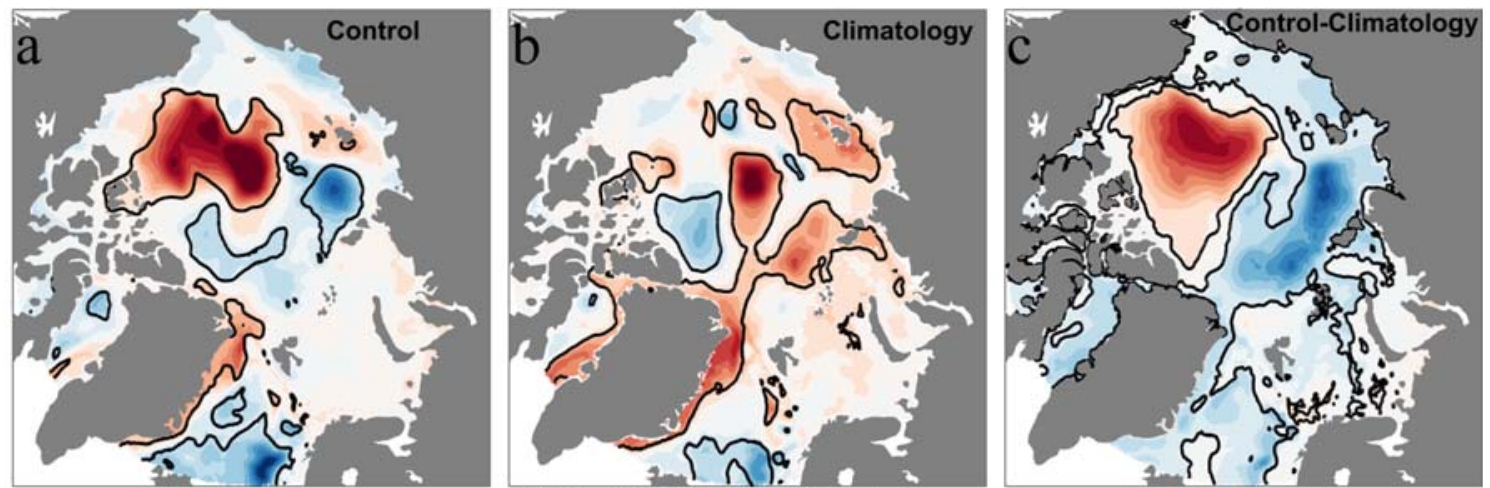

2001-2015 SSH trend $(\mathrm{mm} / \mathrm{yr})$

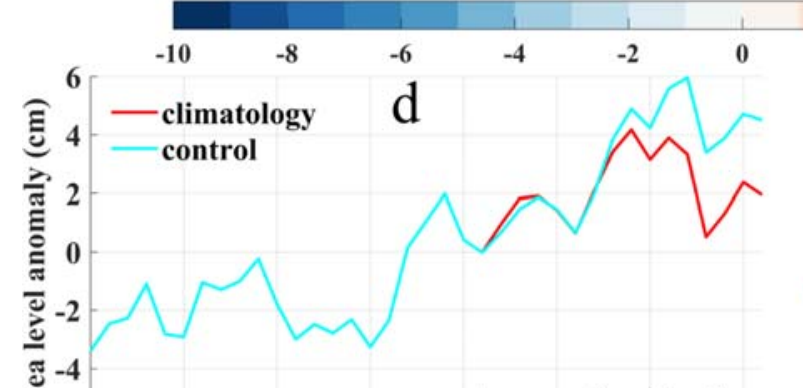

Amerasian Basin
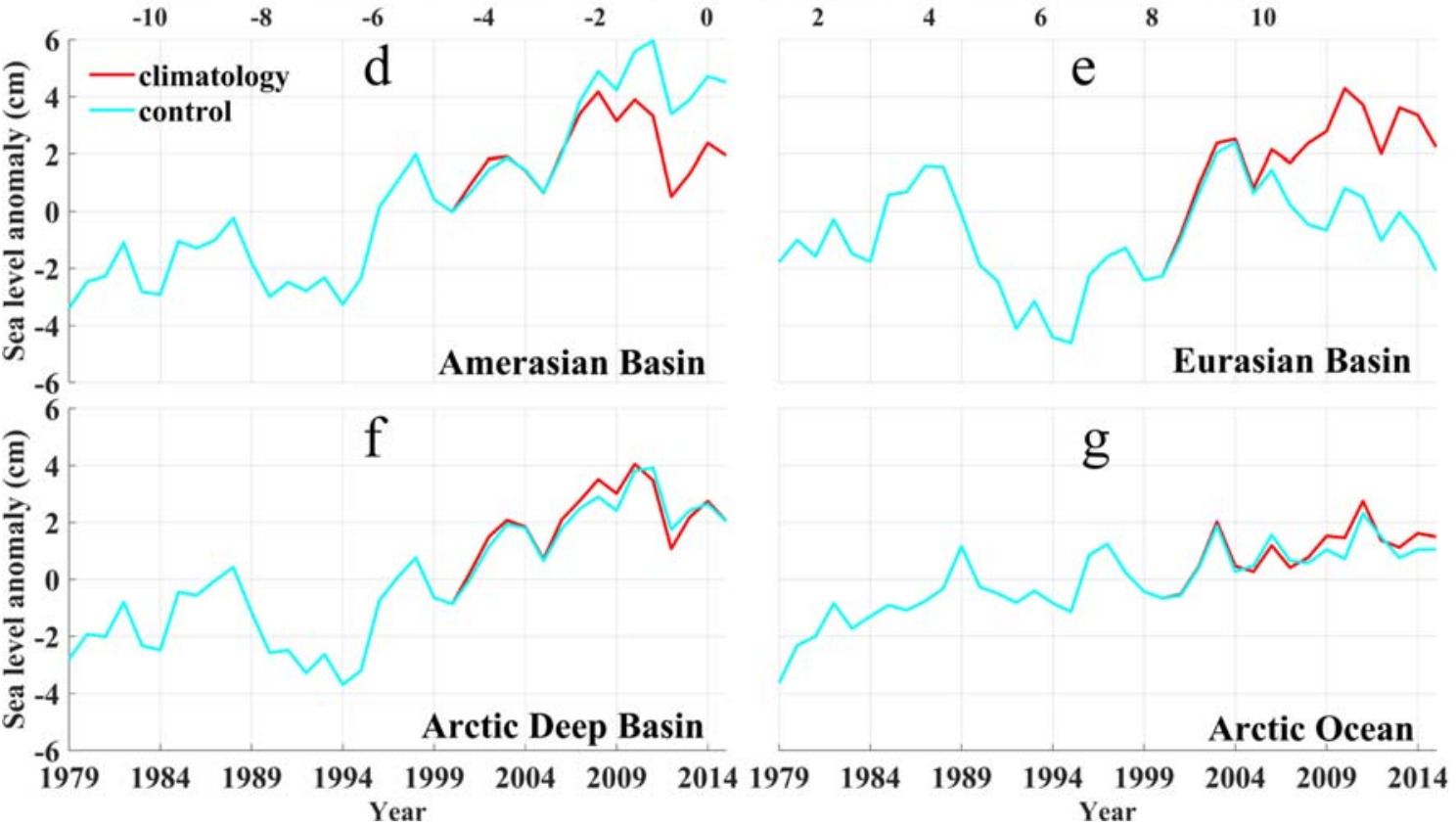

Fig. 9 a, b, c SSH trends for the period 2001-2015 from control and climatology runs and the difference between the two simulations. The black contour lines show the $95 \%$ confidence level. d, e, f, g Anomaly

of SSH in the Amerasian Basin, Eurasian Basin, Arctic deep basin (sum of the two basins), and the entire Arctic Ocean in the control and climatology simulations

The response of the SSH in the two Arctic basins to the sea ice decline is consistent with the impacts of the sea ice decline on the liquid FWC spatial distribution revealed by Wang et al. (2019). They found that the sea ice decline contributes to changes in liquid FWC in the Arctic Ocean in two ways. First, sea ice meltwater reduces the upper ocean salinity, thus increasing the Arctic Ocean liquid FWC. Second, the reduction in sea ice thickness and concentration increases the ocean surface stress, which is in favor of the export of upper-ocean water masses from the Siberian Shelf and the Eurasian Basin towards the Amerasian Basin in the studied period. Along with the retreat of Pacific Water to the American Basin, the proportion of brine Atlantic Water in the upper ocean of the Eurasian Basin increases. The increase of liquid FWC in the Amerasian Basin is nearly compensated by the reduction in the Eurasian Basin. As a result, the total Arctic liquid FWC is almost unchanged with the sea ice decline, but the spatial distribution of the FWC is changed considerably. As the Arctic Ocean SSH variability is dominated by the variability of the halosteric height, the changes of liquid FWC induced by the sea ice decline reported by Wang et al. (2019) well explain the impacts of the sea ice decline on the SSH shown in Fig. 9: it increases the SSH in the Amerasian Basin and reduces the SSH in the Eurasian Basin. Morison et al. (2012) observed a dipole pattern in the change of Arctic SSH between 2005 and 2008, with a decrease in the SSH in the Eurasian Basin and an increase in the Amerasian Basin. As the wind forcing is the same in our two simulations, the fact that such an opposite change is only present in the control run and not in the climatology run (see Fig. 9d, e) indicates that the sea ice decline is responsible for the observed dipole pattern of the SSH change. 


\section{Conclusions}

In this paper, we studied the regional dynamical sea level variability in the Arctic Ocean in the period 1979-2015 using the FESOM simulations. FESOM reasonably reproduces the main spatial pattern of the mean sea surface height (SSH) in the Arctic Ocean over the period 19932012 compared with the DTU13MDT data and over the period 2003-2014 compared with the satellite altimetry data derived by Armitage et al. (2016). Furthermore, the SSH simulated by FESOM has a good correlation with both tide gauge data and the SSH based on satellite altimetry averaged over the Arctic Ocean. It can also reproduce the rapid sea level rise in the Amerasian Basin observed in the last two decades by the altimeter.

To understand the low-frequency variability of the Arctic $\mathrm{SSH}$, we carried out an EOF analysis of the detrended annualmean SSH. The first mode shows an obvious decadal oscillation with the SSH having opposite anomalies in the deep basin and coastal seas. The SSH has a turning point in 1994. In the period 1979-1993, the SSH decreased in the deep basin and increased over the continental shelf; in the period 1994-2010, the SSH increased in the deep basin and decreased over the continental shelf. The decadal SSH variability in the deep basin can be mainly attributed to the halosteric height variability, which is manifested in the variability of liquid FWC.

The first mode of the SSH in the Arctic Ocean is associated with the Arctic Oscillation (AO). The AO drives the decadal variability of the FWC in the Arctic deep basin, thus the variability of the SSH. When AO is predominantly in a negative phase (anomalous anticyclonic winds), as in the period 19942010, surface freshwater is converged towards the Arctic deep basin and the FWC increases, leading to an increase in the SSH in the deep basin. Contemporarily, the release of water masses from marginal seas towards the deep basin reduces the ocean mass, thus reducing the SSH, over the continental shelf. The reduction of SSH in the periphery of the Arctic Ocean allows for a positive anomaly in the net freshwater transport into the Arctic Ocean.

The second mode of the low-frequency SSH variability has anomalies with antiphase between the Amerasian and Eurasian Basins on the decadal timescale, which can be explained by the Arctic dipole anomaly (DA). The wind anomaly associated with the DA redistributes freshwater between the two deep basins, leading to the antiphase SSH variability in the two deep basins.

The significant sea level rise in the Amerasian Basin in recent decades has been mainly attributed to the anticyclonic winds in previous studies (e.g., Proshutinsky et al. 2002, 2015; Giles et al. 2012), which accumulate freshwater through convergence and Ekman downwelling. By using a dedicated sensitivity simulation in which the Arctic sea ice decline is eliminated, in this study, we identified that the recent sea ice decline has contributed considerably to the increasing SSH in the Amerasian Basin. Although the sea ice decline did not change the mean SSH averaged over the whole Arctic Ocean, it significantly increased the SSH in the Amerasian Basin but reduced the SSH in the Eurasian Basin. The effect of the sea ice decline on the SSH is associated with its impacts on the spatial distribution of liquid FWC reported by Wang et al. (2019). They found that the sea ice decline increases the FWC in the Amerasian Basin by both supplying meltwater and shifting the freshwater from the Eurasian Basin towards the Amerasian Basin. The FWC in the Eurasian Basin is consequently reduced. The corresponding changes in the halosteric height thus result in the opposite changes in the SSH in the two Arctic basins. Our results addressed that the impacts of sea ice decline on the regional sea level change in the Arctic Ocean should not be neglected when studying or predicting sea level changes.

Our study revealed two processes that can lead to SSH variations with antiphase between the two Arctic deep basins. One is the wind variability (atmospheric momentum forcing) associated with the DA, and the other is the decline of Arctic sea ice (atmospheric thermal forcing). In certain periods, the antiphase variability can be directly observed (e.g., Morison et al. 2012). However, the AO-driven variability may mask such antiphase variability sometimes. By using EOF decomposition and dedicated numerical experiments, we disentangled these processes and explicitly illustrated their importance in determining the regional sea level change in the Arctic Ocean.

The numerical simulations in this study facilitated to improve our understanding of the variability and trends of the SSH in the Arctic Ocean. Although the model performs relatively well compared with available observations, it shows certain biases in the details of the spatial patterns of the mean SSH and its trend. The results discussed in this paper also provide useful information for future model development.

Acknowledgments We are very thankful to the Technical University of Denmark (DTU) for sharing the mean dynamic topography data of MTD13DTU (ftp.space.dtu.dk/pub/DTU13/). Arctic sea level anomaly data are provided by the Centre for Polar Observation and Modelling, University College London (www.cpom.ucl.ac.uk/dynamic_topography) (Armitage et al. 2016, 2017). Tide gauge data are from the Permanent Service for Mean Sea Level (http://www.psmsl.org/). EN4.2.1 gridded profiles are from Met Office Hadley Center (https://www.metoffice.gov. $\mathrm{uk} / \mathrm{hadobs} / \mathrm{en} 4 /$ ). We thank the anonymous reviewers and the editor for their very helpful comments.

Funding information The study is financially supported by the National Key Research and Development Program of China (Grant 2017YFA0604600) and the National Natural Science Foundation of China (nos. 41576020, 41506006, 41376028, 41676019, and 41976163). QW is supported by the German Helmholtz Climate Initiative REKLIM (Regional Climate Change). 


\section{References}

Andersen O, Knudsen P, Stenseng L (2015) The DTU13 MSS (Mean Sea Surface) and MDT (Mean Dynamic Topography) from 20 Years of Satellite Altimetry. In: Jin S, Barzaghi R (eds) IGFS 2014. International Association of Geodesy Symposia, vol 144. Springer, Cham

Armitage T, Bacon S, Kwok R (2018) Arctic sea level and surface circulation response to the Arctic oscillation. Geophys Res Lett 45:65766584. https://doi.org/10.1029/2018GL078386

Armitage T, Bacon S, Ridout A, Petty A, Wolbach S, Tsamados M (2017) Arctic Ocean surface geostrophic circulation 2003-2014. Cryosphere 11(4):1767-1780. https://doi.org/10.5194/tc-11-17672017

Armitage T, Bacon S, Ridout A, Thomas S, Aksenov Y, Wingham D (2016) Arctic sea surface height variability and change from satellite radar altimetry and GRACE, 2003-2014. J Geophys Res Oceans 121:4303-4322. https://doi.org/10.1002/2015JC011579

Bindoff N, Willebrand J, Artale V et al (2007) Observations: Oceanic climate change and sea level. Climate Change 2007: The Physical Science Basis. S. Solomon et al. Eds, Cambridge University Press, 386-432

Calafat F, Chambers D, Tsimplis M (2013) Inter-annual to decadal sealevel variability in the coastal zones of the Norwegian and Siberian seas: the role of atmospheric forcing. J Geophys Res Oceans 118: 1287-1301. https://doi.org/10.1002/jgrc.20106

Carret A, Johannessen J, Andersen O, Ablain M, Prandi P, Blazquez A et al (2017) Arctic sea level during the satellite altimetry era. Surv Geophys 38(1):251-275

Cazenave A, Llovel W (2010) Contemporary sea level rise. Annu Rev Mar Sci 2:145-173

Cheng Y, Andersen O, Knudsen P (2015) An improved 20-year arctic ocean altimetric sea level data record. Mar Geod 38:146-162

Church J, Clark P, Cazenave A et al (2013) Sea level change. In: Climate change 2013: the physical science basis. Contribution of working group I to the fifth assessment report of the intergovernmental panel on climate change. Cambridge University Press, Cambridge and New York, pp 1137-1216

Danilov S, Wang Q, Timmermann R, Iakovlev N, Sidorenko D, Kimmritz M, Jung T, Schröter J (2015) Finite-element sea ice model (FESIM), version 2. Geosci Model Dev 8:1747-1761

Dmitrenko I, Kirillov S, Tremblay L (2008) The long-term and interannual variability of summer fresh water storage over the eastern Siberian shelf: implication for climatic change. J Geophys Res 113:C03007. https://doi.org/10.1029/2007JC004304

Fukumori I, Wang O, Llovel W, Fenty I, Forget G (2015) A near-uniform fluctuation of ocean bottom pressure and sea level across the deep ocean basins of the Arctic Ocean and the Nordic seas. Prog Oceanogr 134:152-172

Giles K, Laxon S, Ridout A, Wingham D, Bacon S (2012) Western Arctic Ocean freshwater storage increased by wind-driven spin-up of the Beaufort Gyre. Nat Geosci 5:194-197. https://doi.org/10.1038/ ngeo1379

Good S, Martin M, Rayner N (2013) EN4: quality controlled ocean temperature and salinity profiles and monthly objective analyses with uncertainty estimates. J Geophys Res Oceans 118(12):6704-6716. https://doi.org/10.1002/2013JC009067

Griffies S, Yin J, Durack P et al (2014) An assessment of global and regional sea level for years 1993-2007 in a suite of interannual CORE-II simulations. Ocean Model 78:35-89

Henry O, Prandi P, Llovel W, Cazenave A, Jevrejeva S, Stammer D, Meyssignac B, Koldunov N (2012) Tide gauge-based sea level variations since 1950 along the Norwegian and Russian coasts of the Arctic Ocean: contribution of the steric and mass components. J Geophys Res 117:C06023. https://doi.org/10.1029/2011JC007706
Holgate S, Matthews A, Woodworth P et al (2013) New data systems and products at the permanent service for mean sea level. J Coast Res 29(3):493-504. https://doi.org/10.2112/JCOASTRES-D-12-00175.

Ikeda M (1990) Decadal oscillation of the air-ice-sea system in the northern hemisphere. Atmos Ocean 28:106-139

Ikeda M, Wang J, Zhao JP (2001) Hypersensitive decadal oscillations in the Arctic/subarctic climate. Geophys Res Lett 28(7):1275-1278

Jakobsson M, Macnab R, Mayer L et al (2008) An improved bathymetric portrayal of the Arctic Ocean: implications for ocean modeling and geological, geophysical and oceanographic analyses. Geophys Res Lett 35:L07602. https://doi.org/10.1029/2008GL033520

Johannessen J, Raj R, Nilsen J et al (2014) Toward improved estimation of the dynamic topography and ocean circulation in the high latitude and Arctic Ocean: the importance of GOCE. Surv Geophys 35(3):119

Kobayashi S, Ota Y, Harada Y et al (2015) The JRA-55 reanalysis: general specifications and basic characteristics. J Meteorol Soc Jpn Ser II 93(1):5-48. https://doi.org/10.2151/jmsj.2015-001

Köhl A, Serra N (2014) Causes of decadal changes of the freshwater content in the Arctic Ocean. J Clim 27:3461-3475. https://doi.org/ 10.1175/JCLI-D-13-00.389.1

Koldunov N, Serra N, Köhl A et al (2014) Multimodel simulations of Arctic Ocean sea surface height variability in the period 1970-2009. J Geophys Res Oceans 119(12):8936-8954. https://doi.org/10.1002/ 2014JC010170

Kwok R, Cunningham G, Wensnahan M et al (2009) Thinning and volume loss of the Arctic Ocean sea ice cover: 2003-2008. J Geophys Res 114:C07005. https://doi.org/10.1029/2009JC005312

Laxon S (1994) Sea ice altimeter processing scheme at the EODC. Int J Remote Sens 15:915-924. https://doi.org/10.1080/ 01431169408954124

Laxon S, Giles K, Ridout A et al (2013) CryoSat-2 estimates of Arctic sea ice thickness and volume. Geophys Res Lett 40(4):732-737. https:// doi.org/10.1002/grl.50193

Lei R, Heil P, Wang J, Zhang Z, Li Q, Li N (2016) Characterization of sea-ice kinematic in the Arctic outflow region using buoy data. Polar Res 35:22658

Lei R, Leppäranta M, Wang J et al (2015) Changes in sea ice along the Arctic northeast passage since 1979: results from remote sensing data. Cold Reg Sci Technol 119:132-144

Long Z, Perrie W, Tang CL, Dunlap E, Wang J (2012) Simulated interannual variations of freshwater content and sea surface height in the Beaufort Sea. J Clim 25(4):1079-1095. https://doi.org/10.1175/ 2011JCI14121.1

Martin T, Steele M, Zhang J (2014) Seasonality and long term trend of Arctic Ocean surface stress in a model. J Geophys Res Oceans 119: 1723-1738. https://doi.org/10.1002/2013JC009425

McPhee M, Proshutinsky A, Morison J, Steele M, Alkire M (2009) Rapid change in freshwater content of the Arctic Ocean. Geophys Res Lett 36:L10602. https://doi.org/10.1029/2009GL037525

Meyssignac B, Slangen A, Melet A et al (2017) Evaluating model simulations of twentieth-century sea-level rise. Part II: regional sea-level changes. J Clim 30(21):8565-8593

Morison J, Kwok R, Peralta-Ferriz C, Alkire M, Steele M (2012) Changing arctic ocean freshwater pathways. Nature 481(7379):6670

Müller F, Wekerle C, Dettmering D, Passaro M, Bosch W, Seitz F (2019) Dynamic ocean topography of the northern Nordic seas: a comparison between satellite altimetry and ocean modeling. Cryosphere 13: 611-626

Peacock N, Laxon S (2004) Sea surface height determination in the Arctic Ocean from ERS altimetry. J Geophys Res Oceans 109:C07001. https://doi.org/10.1029/2001JC001026 
Peltier W, Argus D, Drummond R (2015) Space geodesy constrains ice age terminal deglaciation: the global ice-6g_c (vm5a) model. J Geophys Res Solid Earth 120(1):450-487

Polyakov I, Bhatt U, Walsh J, Abrahamsen E, Pnyushkov A, Wassmann P (2013) Recent oceanic changes in the Arctic in the context of longterm observations. Ecol Appl 23(8):1745-1764. https://doi.org/10. 1890/11-0902.1

Prandi P, Ablain M, Cazenave A, Picot N (2012a) Sea level variability in the Arctic Ocean observed by satellite altimetry. Ocean Sci Discuss 9(4):2375-2401. https://doi.org/10.5194/osd-9-2375-2012

Prandi P, Ablain M, Cazenave A, Picot N (2012b) A new estimation of mean sea level in the Arctic Ocean from satellite altimetry. Mar Geod 35(sup1):61-81. https://doi.org/10.1080/01490419.2012. 718222

Proshutinsky A, Ashik I, Dvorkin E, Häkkinen S, Krishfield R, Peltier W (2004) Secular sea level change in the Russian sector of the Arctic Ocean. J Geophys Res Oceans 109:C03042. https://doi.org/10. 1029/2003JC002007

Proshutinsky A, Ashik I, Häkkinen S et al (2007) Sea level variability in the Arctic Ocean from AOMIP models. J Geophys Res Oceans 112: C04S08. https://doi.org/10.1029/2006JC003916

Proshutinsky A, Bourke R, Mclaughlin F (2002) The role of the Beaufort Gyre in Arctic climate variability: seasonal to decadal climate scales. Geophys Res Lett 29(23):2100

Proshutinsky A, Dukhovskoy D, Timmermans ML, Krishfield R, Bamber JL (2015) Arctic circulation regimes. Phil Trans R Soc A 373:20140160. https://doi.org/10.1098/rsta.2014.0160

Proshutinsky A, Johnson M (1997) Two circulation regimes of the winddriven Arctic Ocean. J Geophys Res 102(C6):12493-12514

Proshutinsky A, Krishfield R, Timermans M et al (2009) Beaufort Gyre freshwater reservoir: state and variability from observations. J Geophys Res Oceans 114:C00A10. https://doi.org/10.1029/ 2008JC005104

Proshutinsky A, Kowalik Z (2007) Preface to special section on Arctic Ocean model intercomparison project (AOMIP) studies and results. J Geophys Res 112:C04S01. https://doi.org/10.1029/ 2006JC004017

Rabe B, Karcher M, Kauker F, Schauer U, Toole JM, Krishfield RA, Pisarev S, Kikuchi T, Su J (2014) Arctic Ocean basin liquid freshwater storage trend 1992-2012. Geophys Res Lett 41(3):961-968. https://doi.org/10.1002/2013GL058121

Regan H, Lique C, Armitage T (2019) The Beaufort Gyre extent, shape, and location between 2003 and 2014 from satellite observations. J Geophys Res Oceans 124:844-862. https://doi.org/10.1029/ 2018JC014379

Rose S, Andersen O, Passaro M, Ludwigsen C, Schwatke C (2019) Arctic Ocean sea level record from the complete radar altimetry era: 19912018. Remote Sens 11(14). https://doi.org/10.3390/rs11141672

Serreze M, Barrett A, Stroeve J, Kindig D, Holland M (2009) The emergence of surface-based Arctic amplification. Cryosphere 3(1):1119. https://doi.org/10.5194/tc-3-11-2009

Slangen A, Meyssignac B, Agosta C et al (2017) Evaluating model simulations of twentieth-century sea level rise. Part I: global mean sea level change. J Clim 30(21):8539-8563

Stammer D, Cazenave A, Ponte R, Tamisiea M (2013) Causes for contemporary regional sea level changes. Annu Rev Mar Sci 5:21-46. https://doi.org/10.1146/annurev-marine-121211-172406

Stroeve J, Kattsov V, Barrett A, Serreze M, Pavlova T, Holland M, Meier W (2012) Trends in Arctic sea ice extent from CMIP5, CMIP3 and observations. Geophys Res Lett 39(16). https://doi.org/10.1029/ 2012GL052676

Svendsen P, Andersen O, Nielsen A (2016) Stable reconstruction of Arctic sea level for the 1950-2010 period. J Geophys Res Oceans 121(8):5697-5710. https://doi.org/10.1002/2016JC011685
Thompson D, Wallace J (1998) The Arctic Oscillation signature in the wintertime geopotential height and temperature fields. Geophys Res Lett 25(9):1297-1300. https://doi.org/10.1029/98GL00950

Volkov D, Landerer F (2013) Nonseasonal fluctuations of the Arctic Ocean mass observed by the GRACE satellites. J Geophys Res 118:6451-6460. https://doi.org/10.1002/2013JC009341

Wang J, Ikeda M (2000) Arctic Oscillation and Arctic Sea-Ice Oscillation. Geophys Res Lett 27(9):1287-1290

Wang J, Ikeda M (2001) Arctic Sea-Ice Oscillation: regional and seasonal perspectives. Ann Glaciol 33:481-492

Wang J, Ikeda M, Zhang S, Gerdes R (2005) Linking the northern hemisphere sea-ice reduction trend and the quasi-decadal arctic sea-ice oscillation. Clim Dyn 24(2-3):115-130. https://doi.org/10.1007/ s00382-004-0454-5

Wang J, Zhang J, Watanabe E, Mizobata K, Ikeda M et al (2009) Is the dipole anomaly a major driver to record lows in the Arctic sea ice extent? Geophys Res Lett 36:L05706. https://doi.org/10.1029/ 2008GL036706

Wang Q, Danilov S, Sidorenko D, Timmermann R, Wekerle C, Wang X, Jung T, Schroeter J (2014) The Finite Element Sea Ice-Ocean Model (FESOM) v.1.4: formulation of an ocean general circulation model. Geosci Model Dev 7:663-693

Wang Q, Ilicak M, Gerdes R, Drange H, Aksenov Y, Bailey DA, Bentsen $\mathrm{M}$, Biastoch A, Bozec A, Böning C, Cassou C, Chassignet E, Coward AC, Curry B, Danabasoglu G, Danilov S, Fernandez E, Fogli PG, Fujii Y, Griffies SM, Iovino D, Jahn A, Jung T, Large WG, Lee C, Lique C, Lu J, Masina S, Nurser AJG, Rabe B, Roth C, Salas y Mélia D, Samuels BL, Spence P, Tsujino H, Valcke S, Voldoire A, Wang X, Yeager SG (2016a) An assessment of the Arctic Ocean in a suite of interannual CORE-II simulations. Part II: liquid freshwater. Ocean Model 99:86-109

Wang Q, Danilov S, Jung T, Kaleschke L, Wernecke A (2016b) Sea ice leads in the Arctic Ocean: model assessment, interannual variability and trends. Geophys Res Lett 43:7019-7027

Wang Q, Ilicak M, Gerdes R, Drange H, Aksenov Y, Bailey DA, Bentsen $\mathrm{M}$, Biastoch A, Bozec A, Böning C, Cassou C, Chassignet E, Coward AC, Curry B, Danabasoglu G, Danilov S, Fernandez E, Fogli PG, Fujii Y, Griffies SM, Iovino D, Jahn A, Jung T, Large WG, Lee C, Lique C, Lu J, Masina S, Nurser AJG, Rabe B, Roth C, Salas y Mélia D, Samuels BL, Spence P, Tsujino H, Valcke S, Voldoire A, Wang X, Yeager SG (2016c) An assessment of the Arctic Ocean in a suite of interannual CORE-II simulations. Part I: sea ice and solid freshwater. Ocean Model 99:110-132

Wang Q, Wekerle C, Danilov S, Koldunov N, Sidorenko D, Sein D, Rabe B, Jung T (2018a) Arctic Sea ice decline significantly contributed to the unprecedented liquid freshwater accumulation in the Beaufort Gyre of the Arctic Ocean. Geophys Res Lett 45:4956-4964

Wang Q, Wekerle C, Danilov S, Wang X, Jung T (2018b) A 4.5 km resolution Arctic Ocean simulation with the global multiresolution model FESOM 1.4. Geosci Model Dev 11:1229-1255

Wang Q, Wekerle C, Danilov S, Sidorenko D, Koldunov N, Sein D, Rabe B, Jung T (2019) Recent seaice decline did not significantly increase the total liquid freshwater content of the Arctic Ocean. J Clim 32: $15-32$

Wekerle C, Wang Q, Danilov S, Jung T, Schröter J (2013) The Canadian Arctic Archipelago throughflow in a multiresolution global model: model assessment and the driving mechanism of interannual variability. J Geophys Res Oceans 118(9):4525-4541. https://doi.org/ 10.1002/jgrc.20330

Wekerle C, Wang Q, von Appen V, Danilov S, Schourup-Kristensen V, Thomas J (2017a) Eddy-resolving simulation of the Atlantic water circulation in the Fram Strait with focus on the seasonal cycle. J Geophys Res Oceans 122:8385-8405

Wekerle C, Wang Q, Danilov S, Schourup-Kristensen V, von Appen V, Thomas J (2017b) Atlantic water in the Nordic seas: locally eddy- 
permitting ocean simulation in a global setup. J Geophys Res Oceans 122:914-940. https://doi.org/10.1002/2016JC012121

Woodgate R, Weingartner T, Lindsay R (2012) Observed increases in

Bering Strait oceanic fluxes from the Pacific to the Arctic from 2001

to 2011 and their impacts on the Arctic Ocean water column. Geophys

Res Lett 39:L24603. https://doi.org/10.1029/2012GL054092
Wu B, Wang J, Walsh J (2006) Dipole anomaly in the winter Arctic atmosphere and its association with Arctic sea ice motion. J Clim 19(2):210-225. https://doi.org/10.1175/JCLI3619.1

Yin J (2012) Century to multi-century sea-level rise projections from CMIP5 models. Geophys Res Lett 39:L17709. https://doi.org/10. 1029/2012GL052947 